\title{
A FLOW CHANNEL WITH NAFION MEMBRANE MATERIAL DESIGN OF PEM FUEL CELL
}

\author{
T. Taner ${ }^{1, *}$
}

\begin{abstract}
This study is about flow channels in the design of the PEM (Proton Exchange Membrane) fuel cell system. In the experimental study, different flow geometry, Nafion membrane, and bipolar plate gas diffusion channel designs are available. In some cases, the techno-economic analysis method is applied. Cost analysis for the design has also been made and compared with similar studies. It was obtained that the new flow channel design increased the PEM fuel cell performance. A unit energy cost was set to 42.6 [\$/W]. When a similar system was implemented for a year, the annual energy cost was calculated to be 25.48 [ $\$ / y]$. The aim of this study is to determine the cost-benefit analysis of PEM fuel cell with a combined flow channel design. In addition, the simple payback period was found to be $0.81[\mathrm{y}]$. Thus, the PEM fuel cell was determined by the techno-economic analysis calculation, in which energy savings can be achieved by the flow channel design.
\end{abstract}

\section{Keywords: PEM Fuel Cell, Membrane, Gas Diffusion Channel, Cost Analysis}

\section{INTRODUCTION}

This century is the age of advanced technology as well as brings current many energy problems. Therefore, many countries need to produce energy to sustain their lives and developments. Developed and developing countries are looking for ways to make sustainable and renewable energy work more efficiently. Many of these countries are working hard to develop similar energy sources, such as wind energy, solar energy, biomass, fuel cell, wave energy and hydrogen energy, which focus on renewable energy sources.

In particular, the fuel cell is becoming an alternative source of energy and increasing its use. As PEM fuel cell performance is high and efficient, the demand for PEM fuel cell is growing. Thus, PEM fuel cell design attracts great attention in all areas of interest to energy systems. PEM fuel cell design energy system technology development and R \& D work are supported by many countries and companies. PEM fuel cell design energy systems are expected to be used in many sectors in energy production processes.

Scientists and companies working in this field attach great importance to PEM fuel cell design systems. In addition to PEM fuel cells, hydrogen production becomes more important. NASA, especially for Mars and other remote lives, continues its work on fuel cells and hydrogen systems that are seeking alternative energy systems.

This study investigated the techno-economic analysis of PEM fuel cell in combined flow channels. This study also takes part in similar studies in the literature and is an ongoing study of the previous research project. There are many studies in PEM fuel cell studies, especially in terms of modeling and analysis methods and these studies are related to parameters as well as optimizations [1-6].

In the previous experimental study, PEM mentions that the performance of the fuel cell in terms of pressure and voltage parameters can produce energy at optimum conditions [7]. This study is to model PEM fuel cell flow channels with energy performance and efficiency design. The subject of this study is the PEM fuel cell performance analysis, as well as energy analysis and techno-economic analysis [8-13]. In another experimental study, the open system PEM is about the effect of the fuel cell on the performance of volts, currents, mass air flows and other parameters in the literature [14].

Thanks to this study, performance parameters of PEM fuel cells are investigated by optimizing PEM fuel cell performance and wastewater management conditions. In the PEM fuel cell, parameter changes were applied to the fuel cell to make the performance more efficient under optimum conditions.

Many studies have used Nafion material, which improves performance in the PEM fuel cell and is good strength in terms of durability [15-16]. Bao et al. [17] explained that moisture is a very important parameter that This paper was recommended for publication in revised form by Editor Hafiz Muhammad Ali ${ }^{1}$ Department of Motor Vehicles and Transportation Technology, Aksaray University, Aksaray, TURKEY ${ }^{*}$ E-mail address: tolgataner@aksaray.edu.tr 
affects fuel cell performance. Zhang et al. [18] observed and interpreted the performance of PEM fuel cells. Zhang et al. [19] indicated that the PEM fuel cell could affect water intake and output performance in both experimental and theoretical studies.

Nafion material was used in this study. With this study, PEM (Proton Exchange Membrane) fuel cell is designed new flow channels and materials that can improve the energy performance by affecting the flow gas flow in fuel cells.

In addition, Arababi et al. [20] stated that water management, mass and water transfer are important in the PEM fuel cell system. Dokkar et al. [21] studied the content and properties of the fuel cell membrane, parameter effects, and ionic conductivity studies. Mirzaei et al. [22] studied the strength and performance of the hydrothermal synthesized platinum multi-walled carbon nanotube nanocomposite catalyst for PEM fuel cell. La Manna et al. [23] investigated the pressure gradients and relative humidity of the fuel cell membrane electrode installation. Kong et al. [24] showed that the rapid administration of water management from the PEM fuel cell gas diffusion layer had an enormous effect on performance.

When the literature is reviewed, there are many studies on temperature, voltage, current and flow rates of fuel cell parameters. In this experimental study, the parameters similar to the previous studies were researched by means of the design of the flow channels. In addition, the cost analysis was calculated according to optimized conditions.

The main objective of this study is to optimize the flow channels of PEM fuel cells and to highlight similar studies in the future by emphasizing the significance of bipolar plate and gas diffusion layers. Thus, it is shown that new approaches to fuel performance of Proton Exchange Membrane fuel cell flow channels will occur with parameter changes.

During the experimental work of the manufactured PEM fuel cell (BAP project 2018-003), the work was successfully completed by using electric current cables as well as the power unit, air flow meter pump, pressure regulator and other hydrogen gas air duct cables from the previous BAP (2016-030) project. The research project was made considering some optimal conditions. As a result, the manufactured PEM fuel cell (BAP project 2018-003) was found to be more optimal than the previous project. It contributes to science both in terms of originality and in terms of novelty and design.

\section{MATERIALS AND METHODS}

PEM fuel cell system was experimentally studied in order to improve fuel cell performance by using different material membranes with different flow channels. Furthermore, the most effective solution with different flow channels design was produced by trying different combinations with laser cutting. The experimental study determined a method for different conditions in this direction. Therefore, membrane production and flow channel design were selected according to optimum conditions for experimental use.

The materials used for the design and manufacture of the fuel cell are given in the following list of material properties and dimensions were given in Table 1. Graphite Bipolar Plate has a 5 x $5 \mathrm{~cm}$ active area single surface treated with specified design. In this study, graphite material was chosen as fuel cell material because the graphite material reacts faster and provides better energy transfer. Carbon Paper has been made with 7 x $7 \mathrm{~cm}$ Avcard GDS3215 material. Silicone \& Teflon Gasket's dimension is $10 \times 10 \mathrm{~cm}$ thickness. Standard MEA with Nafion 212 Membrane has a $25 \mathrm{~cm}^{2}$ active area. In addition, gasket and GDL (gas diffusion layer) die cutting material were used for fuel cell directory.

Table 1. The list of material properties and dimensions

\begin{tabular}{|c|l|l|}
\hline No & Material Properties & Dimensions \\
\hline 1 & Graphite Bipolar Plate (single surface treated with the specified design) & $\begin{array}{l}5 \times 5 \mathrm{~cm} \mathrm{active} \\
\text { area }\end{array}$ \\
\hline 2 & Carbon Paper (Avcard GDS3215 material) & $7 \times 7 \mathrm{~cm}$ \\
\hline 3 & Silicone \& Teflon Gasket (thickness) & $10 \times 10 \mathrm{~cm}$ \\
\hline 4 & Standard MEA with Nafion 212 Membrane & $25 \mathrm{~cm}^{2}$ active area \\
\hline 5 & $\begin{array}{l}\text { Gasket and GDL (gas diffusion layer and catalyst layer) die cutting } \\
\text { material }\end{array}$ & $25 \mathrm{~cm}^{2}$ \\
\hline
\end{tabular}


Figure 1, which shows the individual materials and components used in the PEM fuel cell array, indicates materials and parts of the PEM fuel cell directory. In Figure 1a, GDL (Gas Diffusion Layer), which is shown, provides the transmission and transmission of gas. GDL was produced from graphite material with the design of flow channels. In Figure 1b, silicone gasket's dimensions are $40 \mathrm{~cm} \mathrm{x} 40 \mathrm{~cm}$ and $1 \mathrm{~mm}$ thickness. Silicone gasket provides the montage for damping resistance force of PEM fuel cell. In Figure 1c, carbon paper dimensions are $40 \mathrm{~cm}$ x $40 \mathrm{~cm}$ and are made of Avcard GDS3215. Carbon paper plays a role in energy production by providing gas porosity property in the fuel cell. In Figure 1d, catalyst layer material is shown in detail figure. This layered material ensures the catalyst active action from anode to the cathode for PEM fuel cell. In Figure 1e, graphite bipolar plate is produced with $25 \mathrm{~cm}^{2}$ active area single surface treated with specified design.
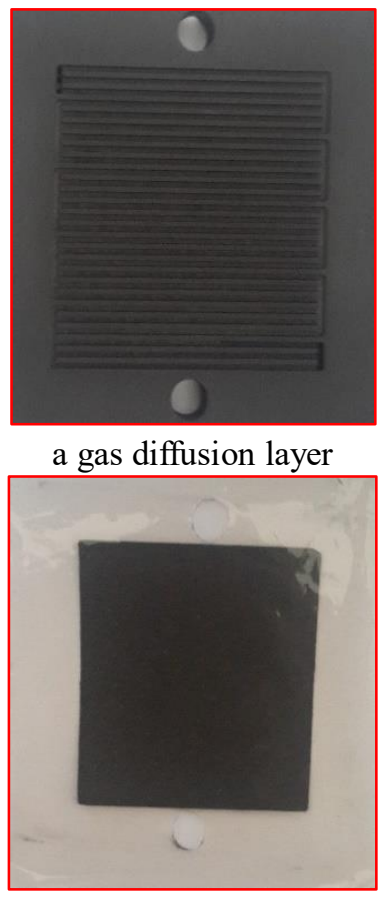

c- carbon paper

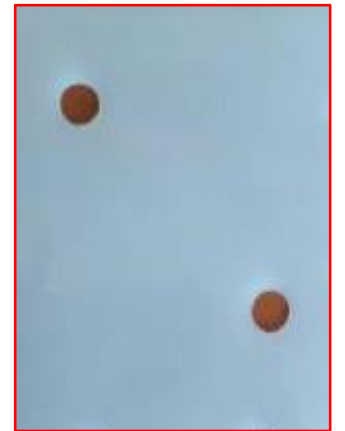

b-silicone gasket

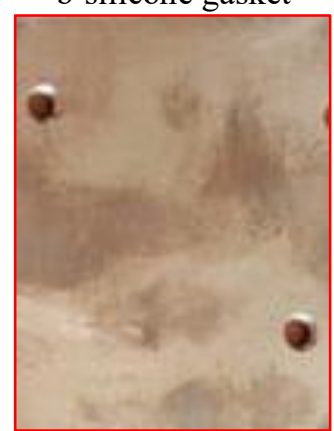

d-catalyst layer

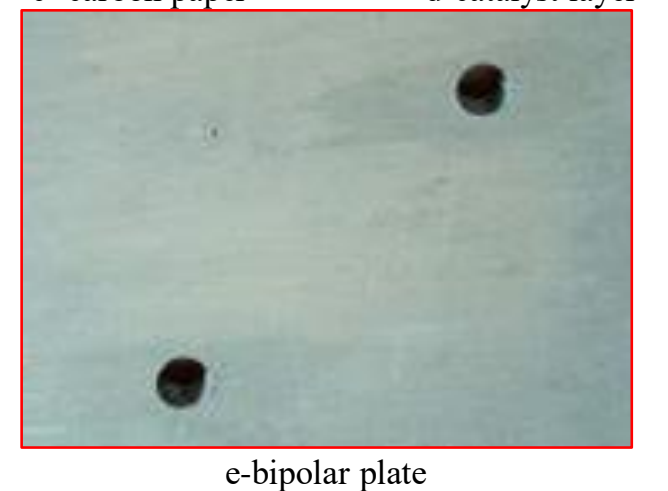

Figure 1. Detailed view of the materials of the PEM fuel cell

Figure 2 shows the assembly of the PEM fuel cell system with different flow channel design. In Figure 2, the flow channel, which is one of the assembled fuel cell parts, is made of graphite material and its design is made by laser cutting. This graphite material is one of the most suitable materials for PEM fuel cell energy transfer and transmission and it is a high-performance material. Apart from the selection and use of these materials, Nafion 212 membrane film and carbon paper were combined as fuel cell membrane to obtain the membrane product to provide optimum gas permeability. Furthermore, it is seen from the shapes in which the 
flow channel in the PEM fuel cell is designed and produced from graphite material other than silicon and bipolar plates.

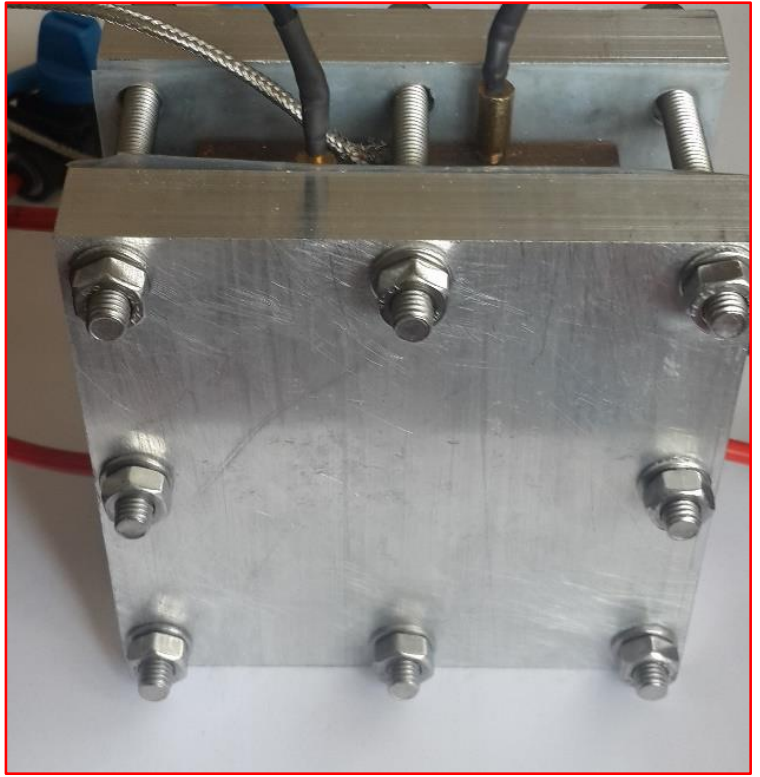

a- PEM fuel cell side view

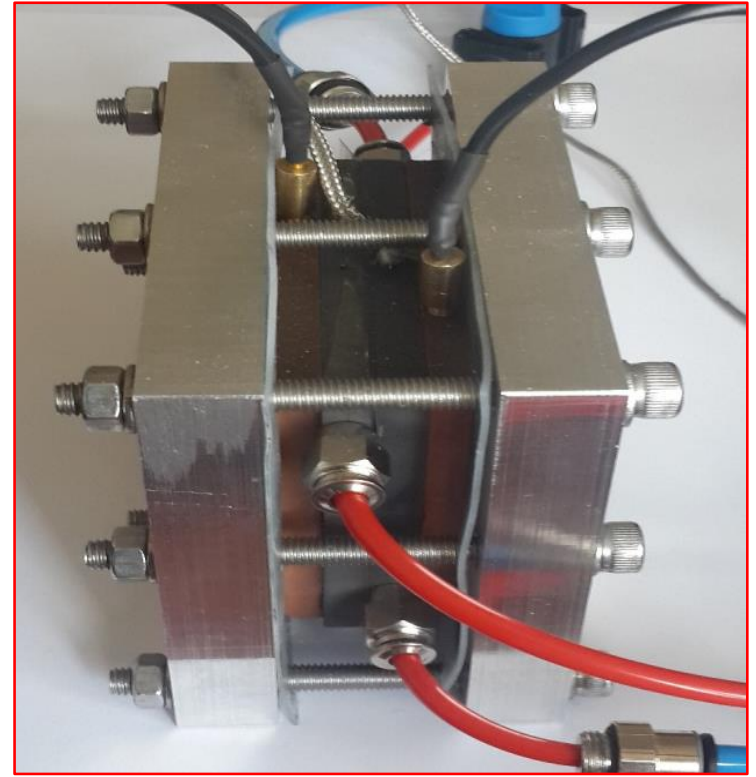

b- PEM fuel cell vertical view

Figure 2. A view of PEM fuel cell montage

Figure 2a shows the PEM fuel cell side view. Figure $2 \mathrm{~b}$ shows the PEM fuel cell vertical view. These figures present the final production and montage of the PEM fuel cell, which is set up for energy production. A total of 8 metric stud bolts and nuts were used in the PEM fuel cell assembly. Bipolar plates with gas diffusion flow channels were used to form the anode and cathode portions of the PEM fuel cell. Membrane and carbon paper was used in the middle of the fuel cell array to provide energy transfer and permeability. Bipolar plates with gas diffusion flow channel design (circulating hydrogen gas) were used for energy production. Subsequently, the catalysis layer was used on both sides. On the outermost, bipolar plates were designed with silicone material and assembled with studs and bolts.

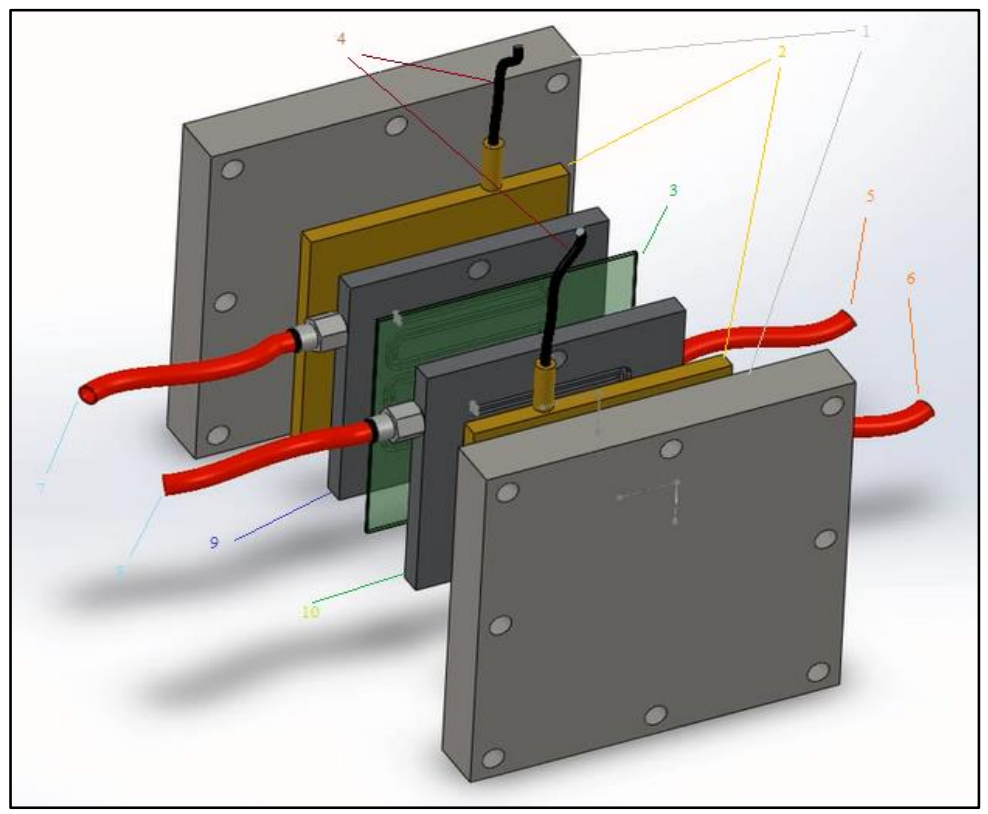

Figure 3. PEM fuel cell directory by drawing Solidworks programme 
Figure 3 presents the PEM fuel cell directory by drawing Solidworks programme. Materials and actions are numbered in the PEM fuel cell range. Part 1 consists of a steel alloy bipolar layer. Part 2 is the copper alloy parts of the catalysis layer. Part 3 is a membrane consisting of Nafion 212 material and carbon paper. Part 4 is thermocouple and controls the fuel cell temperature. Part 5 is the hydrogen gas outlet. Part 6 shows oxygen gas and $\mathrm{H} 2 \mathrm{O}$ output. Part 7 is the hydrogen gas inlet. Part 8 is the oxygen gas inlet pipe. Part 9 is an anode graphite material gas flow channel. Part 10 is a graphite gas flow channel where the cathode reaction takes place.

In terms of method and scope, energy efficiency and techno-economic analysis of PEM fuel cell emerge by applying optimizations in the factors affecting the fuel cell such as current, volts, pressure, power, flow rate, and air. Production and design based flow model studies are carried out and a more efficient fuel cell system is obtained. It plays a key role in the success of this project. Energy efficiency results are particularly effective due to power, volt and current optimizations and advanced simulation modeling (flow mass flow rate and pressure parameter optimizations).

\section{ENERGY PRODUCTION AND COST ANALYSIS}

In this study, the costs of the materials required for the design and design of the PEM fuel cell were calculated to calculate the techno-economic analysis. These materials are respectively; Nafion membrane, catalyst layer, carbon paper, GDL (Gas Diffusion Layer) graphite material, silicone gasket and bipolar plates.

In Figure 4, the PEM fuel cell mass and energy balance flow scheme diagram are presented in detail. In addition, the hydrogen gas tank is 10 [1] in the experiment. Before starting the PEM fuel cell assembly, the $\mathrm{H}_{2}$ tank was filled with $\mathrm{H}_{2}$ gas from a large industrial cylinder resistant to $\mathrm{H}_{2} 400$ bar pressure. As shown in Figure 4, the tank $\mathrm{H}_{2}$ is calibrated with a pressure gauge to operate the power supply. In addition, the air supply device is actuated to supply $\mathrm{O}_{2}$ gas from the air and increase the air flow rate. Subsequently, the PEM fuel cell starts operating and energy production from $\mathrm{H}_{2}$ gas begins. Furthermore, the wastewater generated by the combination of $\mathrm{H}_{2}$ and $\mathrm{O}_{2}$ gases in the fuel cell is discharged from the cells.

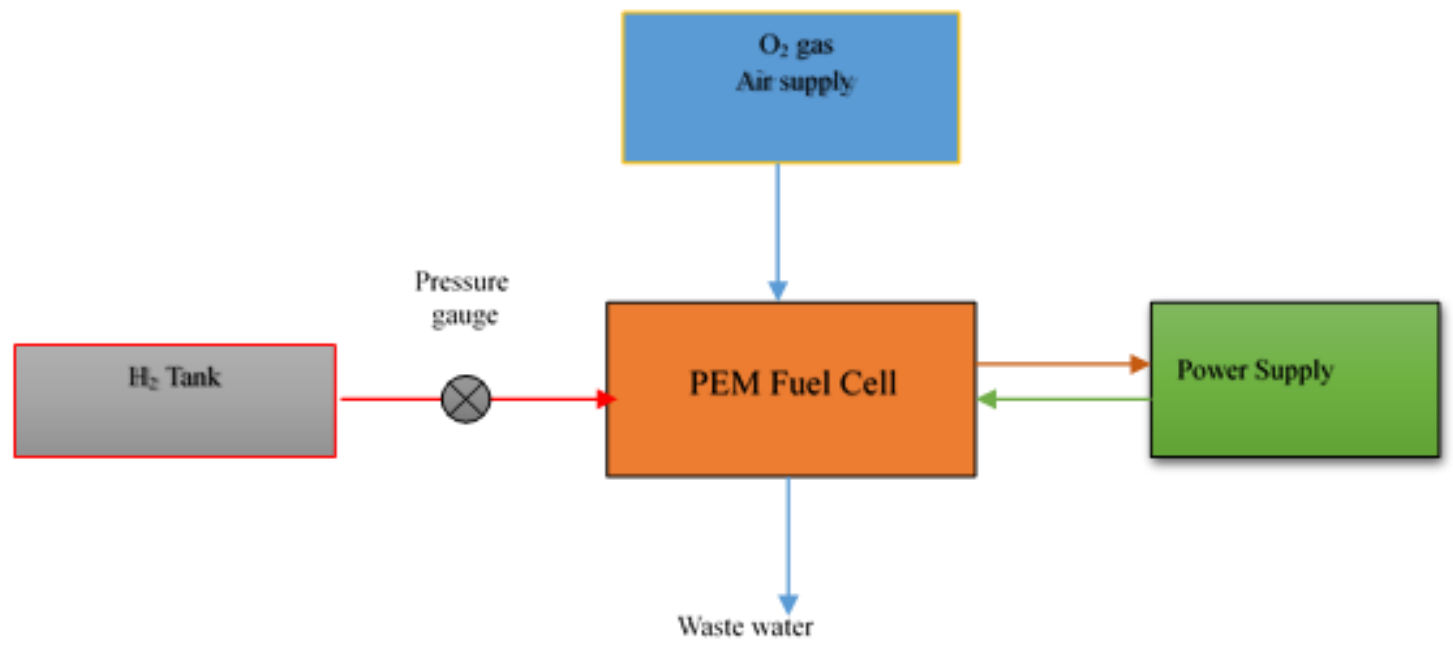

Figure 4. A diagram of PEM fuel cell mass and energy balance flow scheme

Before the calculation of the energy cost and production, some important mass and energy information about hydrogen gas should be given. It is assumed that the low-temperature value for hydrogen gas is about 120 $\mathrm{MJ} / \mathrm{kg}$ and the hydrogen gas density is about $0.08[\mathrm{~g} / \mathrm{l}]=\left[\mathrm{kg} / \mathrm{m}^{3}\right]$. at normal temperature and pressure $[7,25]$. Firstly, the maximum amount of energy production can be calculated from Eq. (1) to Eq. (3) as follows [8-9, 25]:

$$
\begin{aligned}
& \mathrm{m}[\mathrm{kg}]=\rho\left[\mathrm{kg} / \mathrm{m}^{3}\right] \times v\left[\mathrm{~m}^{3}\right] \\
& \mathrm{En}[\mathrm{J}]=\mathrm{Hu}[\mathrm{J} / \mathrm{kg}] \times \mathrm{m}[\mathrm{kg}]
\end{aligned}
$$




$$
\mathrm{t}[\mathrm{s}]=\mathrm{P}_{\mathrm{PEM}}[\mathrm{W}] \times \mathrm{En}[\mathrm{J}]
$$

Some similar previous similar studies execute the cost analysis for energy cost for the techno-economic analysis. An energy cost unit can be calculated from Eq. (4) as follows [26-28]:

$$
\begin{gathered}
\dot{\mathrm{C}}_{\mathrm{En}}[\$ / \mathrm{W}]=\frac{\mathrm{C}_{\text {cost }}[\$]}{\mathrm{P}_{\mathrm{PEM}}[\mathrm{W}]} \\
\mathrm{C}_{\mathrm{y}}[\$ / \mathrm{y}]=\mathrm{Q}[\mathrm{kg} / \mathrm{y}] \times \mathrm{P}_{\mathrm{H} 2}[\$ / \mathrm{kg}]
\end{gathered}
$$

$\mathrm{C}_{\mathrm{y}}$, which is the total energy yield, is the multiplication of the $\mathrm{H}_{2}$ gas price and the system of PEM fuel cell mass flow. The unit of energy consumption can be defined as $\dot{C}_{\mathrm{En}}$ is. $\mathrm{C}_{\text {cost }}$ is the cost of PEM fuel cell materials and maintenance cost. From Eq. (6), $\mathrm{C}_{\text {cost }}$ is the PEM fuel cell cost.

Simple payback period $\left(\mathrm{P}_{\mathrm{SPP}}\right)$, which is to analyze the financial performance, explains as energy payback time and can prove the profitability evaluation for the system. The simple payback period can be defined as follows [25, 29-31]:

$$
\mathrm{P}_{\mathrm{SPP}}=\frac{\mathrm{C}_{\mathrm{cost}}}{\mathrm{Cy}}
$$

In addition, the reaction should be defined clearly. So, the reaction between $\mathrm{H}_{2}$ and $\mathrm{O}_{2}$ gas can be given in Eq. (7) as below [7, 14, 32-37]:

$$
\mathrm{H}_{2}+\frac{1}{2} \mathrm{O}_{2} \rightarrow \mathrm{H}_{2} \mathrm{O} \text { energy }+ \text { heat of the waste }
$$

The fuel cell anode reaction and cathode can be given in Eq. (8) and Eq. (9), respectively as below:

$$
\begin{gathered}
\text { Anode: } \mathrm{H}_{2} \rightarrow 2 \mathrm{H}^{+}+2 \mathrm{e}^{-} \\
\text {Cathode: } \frac{1}{2} \mathrm{O}_{2}+2 \mathrm{H}^{+}+2 \mathrm{e}^{-} \rightarrow \mathrm{H}_{2} \mathrm{O}
\end{gathered}
$$

PEM fuel cell's balance of mass amount can be given in Eq. (10) as follows:

$$
\Sigma \mathrm{m}_{\text {in }}=\Sigma \mathrm{m}_{\text {out }}
$$

The notion of the current I can be given as the symbol I with unit [A], the Faraday constant F can be given as 96485 [C / mol], and $\mathrm{n}$ is the ratio of hydrogen gas molar. The equation of the current calculation can be given in Eq. (11) as follows [33, 35, 36, 38]:

$$
\mathrm{I}[\mathrm{A}]=2 \mathrm{~F}[\mathrm{C} / \mathrm{mol}] \times \mathrm{n}_{\mathrm{H} 2}[\mathrm{~mol}]
$$

PEM fuel cell's efficiency can be calculated from Eq. (12) as follows:

$$
\eta_{\text {cell }}=\frac{\mathrm{v}_{\text {cell }}}{1.48}
$$

In Eq. (13), the production of heat transfer $\mathrm{Q}_{\mathrm{H}}$ [W] can be determined as below [39]: 


$$
\dot{\mathrm{Q}}_{\mathrm{H}}=\mathrm{W}_{\text {net }}\left(\frac{1.25}{\mathrm{~V}_{\text {cell }}}-1\right)
$$

\section{RESULTS AND DISCUSSION}

The result of this experimental study is given in the section according to the techno-economic analysis with energy production of the PEM fuel cell. In the previous study, these results indicated that the experimental study is very important for the PEM fuel cell durability and life of water waste [7]. The results of this study were similar to the previous study. In particular, it was observed that the control of water production in the PEM fuel cell increased the life and durability of the fuel cell [7]. It has been confirmed that if the amount of water production can be reduced by optimization, the life and cost of the PEM fuel cell can also increase.

In Table 2, the results of the energy analysis can be presented for the energy cost. The mass of the gas was found to be 0.0008 [kg]. Cases of this study were determined as $2[\mathrm{~W}], 5[\mathrm{~W}]$ and 7 [W]. The production time of cases were found to be $13.3[\mathrm{~h}], 5.3[\mathrm{~h}]$ and $3.8[\mathrm{~h}]$. The flow rates of cases were calculated as 0.52 $[\mathrm{kg} / \mathrm{y}], 1.3[\mathrm{~kg} / \mathrm{y}]$ and $1.82[\mathrm{~kg} / \mathrm{y}]$.

Table 2. The energy features of PEM fuel cell results

\begin{tabular}{|c|c|c|c|}
\hline Energy features & $\begin{array}{l}\text { Case 1 } \\
2[\mathrm{~W}]\end{array}$ & $\begin{array}{l}\text { Case } 2 \\
5[W]\end{array}$ & $\begin{array}{l}\text { Case } 3 \\
7[\mathrm{~W}]\end{array}$ \\
\hline $\mathrm{m}[\mathrm{kg}]$ & 0.0008 & 0.0008 & 0.0008 \\
\hline En $[\mathrm{J}]$ & 96000 & 96000 & 96000 \\
\hline $\mathrm{t}[\mathrm{s}]$ & 48000.0 & 19200.0 & 13714.3 \\
\hline $\mathrm{t}[\mathrm{h}]$ & 13.3 & 5.3 & 3.8 \\
\hline $\mathrm{Q}[\mathrm{kg} / \mathrm{h}]$ & $6 \times 10^{-5}$ & $15 \times 10^{-5}$ & $21 \times 10^{-5}$ \\
\hline $\mathrm{Q}[\mathrm{kg} / \mathrm{y}]$ & 0.52 & 1.30 & 1.82 \\
\hline
\end{tabular}

In Table 2, energy production is to be found as $96000[\mathrm{~J}]$ and spend the time of energy usage can be from $3.8[\mathrm{~h}]$ to 13.3 [h] for the PEM fuel cell system. 10 [1] is the end time of the hydrogen gas in the tank.

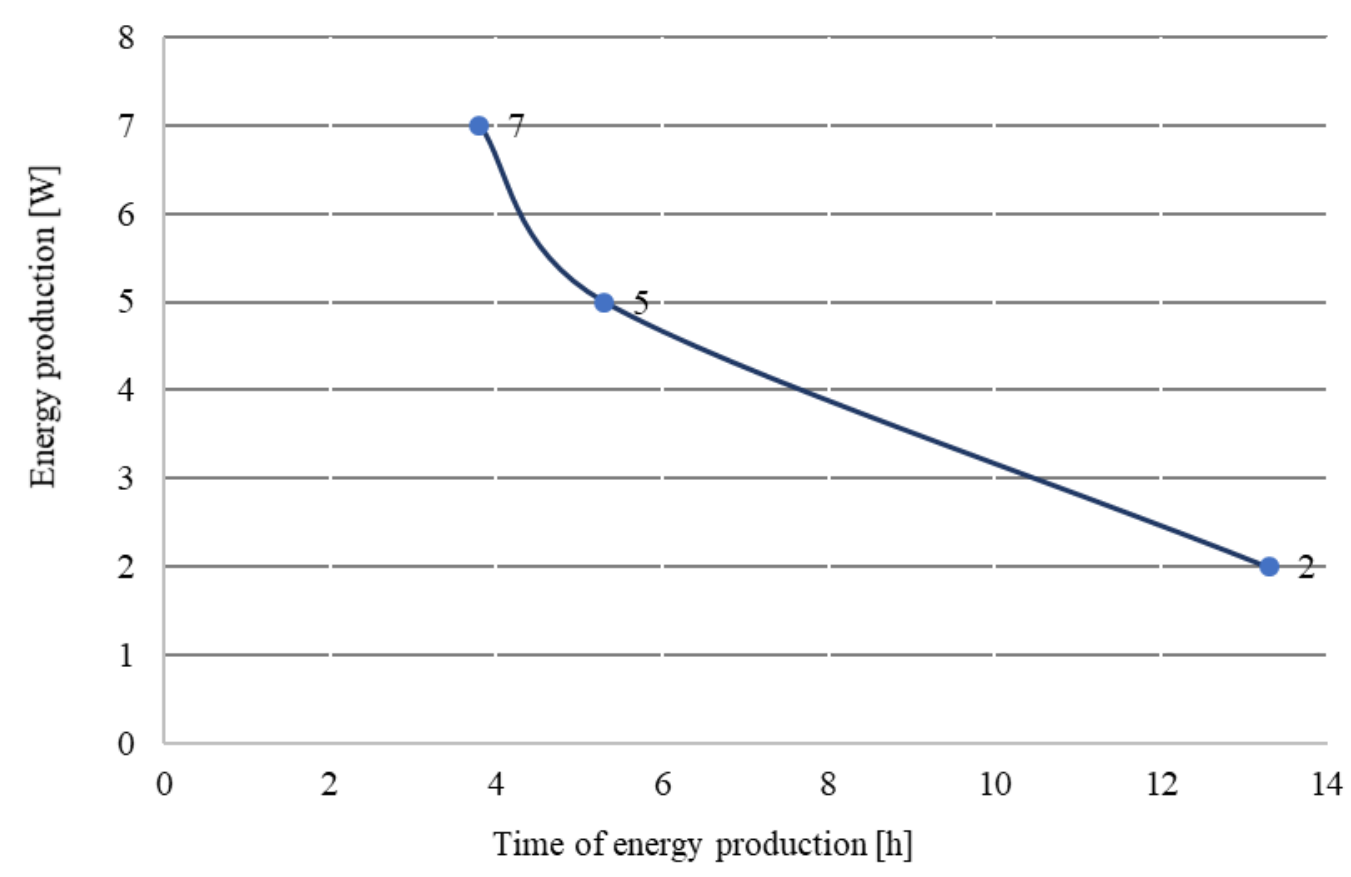

Figure 4. A diagram of PEM fuel cell energy production

In Figure 4, it can be seen a diagram of PEM fuel cell energy production. When the graph is analyzed, the energy generation time is shortened as the PEM fuel cell power supply reaches 7 [W]. However, the power generation time is prolonged when the PEM fuel cell power supply is set to 2 [W]. 
In Table 3, the total cost of PEM fuel cell material and maintenance $\left(\mathrm{C}_{\text {cost }}\right)$ are about 20.7 [\$]. This PEM fuel cell can produce energy (En) as maximum 7 [W] in the system. It can be calculated as an energy cost. These cost are given as respectively; the Nafion membrane cost is 3.85 [\$], bipolar plate cost is 12 [\$], catalyst layer cost is 2.5 [\$], carbon paper cost is 4 [\$], silicone gasket cost is 1 [\$] and the maintenance of a system cost is 2 $[\$]$.

Table 3. The cost of PEM fuel cell materials

\begin{tabular}{|l|l|l|l|}
\hline N. & Material description & Item & Cost [\$] \\
\hline 1 & Nafion membrane & 1 & 3.85 \\
\hline 2 & Bipolar plates & 2 & 24 \\
\hline 3 & Catalyst Layer & 2 & 5 \\
\hline 4 & Carbon paper & 1 & 4 \\
\hline 5 & Silicone gasket & 2 & 2 \\
\hline 6 & Maintenance & 1 & 2 \\
\hline \multicolumn{2}{|c|}{ The total cost of PEM Fuel Cell [\$] } & 20.7 \\
\hline
\end{tabular}

In Table 4, the results of the cost analysis are given below. According to the Table 4, the simple payback periods are determined as respectively follows; 2.84 [y] of Case 1, 1.14 [y] of Case 2 and 0.81 [y] of Case 3.

Table 4. The results of the cost analysis (Techno-economic analysis)

\begin{tabular}{|c|c|c|c|}
\hline Techno-economic analysis & $\begin{array}{l}\text { Case } 1 \\
2[\mathrm{~W}]\end{array}$ & $\begin{array}{l}\text { Case } 2 \\
5[W]\end{array}$ & $\begin{array}{l}\text { Case } 3 \\
7[\mathrm{~W}]\end{array}$ \\
\hline$C_{\text {cost }}[\$]$ & 20.7 & 20.7 & 20.7 \\
\hline$\dot{\mathbf{C}}_{\text {En }}[\$ / \mathbf{W}]$ & 149 & 59.6 & 42.6 \\
\hline $\mathbf{C}_{\mathbf{y}}[\mathbf{\$} / \mathbf{y}]$ & 7.28 & 18.20 & 25.48 \\
\hline P $_{\text {SPP }}[\mathbf{y}]$ & 2.84 & 1.14 & 0.81 \\
\hline
\end{tabular}

In Table 5, the results of the cell of voltage and performance efficiency are given the detail of version.

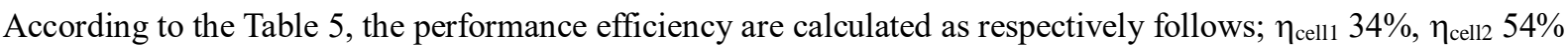
and $\eta_{\text {cell3 }} 68 \%$.

Table 5. The results of the cell of voltage and performance efficiency

\begin{tabular}{|c|c|c|c|}
\hline & $\mathbf{V}_{\text {cell1 }}=\mathbf{0 . 5}$ & $\mathbf{V}_{\text {cell2 }}=\mathbf{0 . 8}$ & $\mathbf{V}_{\text {cell3 }}=\mathbf{1 ~ . 0}$ \\
\hline $\mathbf{V}_{\text {cell }}$ & 0.5 & 0.8 & 1.0 \\
\hline$\eta_{\text {cell }}$ & 0.34 & 0.54 & 0.68 \\
\hline
\end{tabular}

In Figure 5, it can be seen a diagram of PEM fuel cell voltage and performance efficiency. The performance of efficiency $\mathrm{V}_{\text {cell3 }}$ is the best one, however voltage is the biggest one. So, $\mathrm{V}_{\text {cell2 }}$ optimisation can be used to get the best perfomance for the PEM fuel cell. In addition, the ratio of the performance is near to the usage of the voltage amount. 


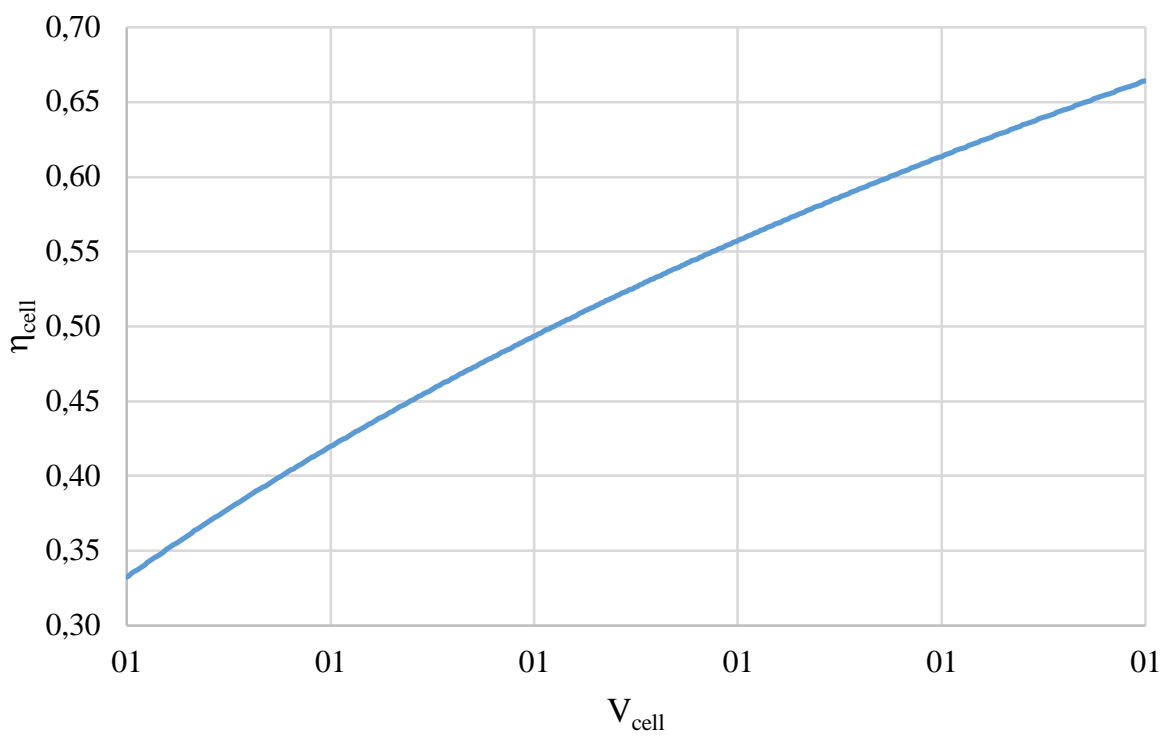

Figure 5. A diagram of PEM fuel cell voltage and performance efficiency

In Table 6, the results of the PEM fuel cell's heat transfer are presented the according to the Cases. According to the Table 6, the heat transfer of cases are calculated as respectively follows; $\mathrm{Q}_{\mathrm{H}}$ is found to be 3 [W] according to the $\eta_{\text {cell1 }}$ (Case $1-2[\mathrm{~W}]$ ), $\mathrm{Q}_{\mathrm{H}}$ is found to be $1.1[\mathrm{~W}]$ according to the $\eta_{\text {cell2 }}$ (Case $1-2[\mathrm{~W}]$ ), and $\mathrm{Q}_{\mathrm{H}}$ is found to be $0.5[\mathrm{~W}]$ according to the $\eta_{\text {cell3 }}$ (Case $\left.1-2[\mathrm{~W}]\right)$. $\mathrm{Q}_{\mathrm{H}}$ is found to be $7.5[\mathrm{~W}]$ according to the $\eta_{\text {cell1 }}($ Case $1-5[\mathrm{~W}]), \mathrm{Q}_{\mathrm{H}}$ is found to be $2.8[\mathrm{~W}]$ according to the $\eta_{\text {cell2 }}$ (Case $1-5[\mathrm{~W}]$ ), and $\mathrm{Q}_{\mathrm{H}}$ is found to be $1.3[\mathrm{~W}]$ according to the $\eta_{\text {cell3 }}$ (Case $1-5[\mathrm{~W}]$ ). $\mathrm{Q}_{\mathrm{H}}$ is found to be $10.5[\mathrm{~W}]$ according to the $\eta_{\text {cell1 }}$ (Case $1-7$ $[\mathrm{W}]), \mathrm{Q}_{\mathrm{H}}$ is found to be $3.9[\mathrm{~W}]$ according to the $\eta_{\text {cell2 }}$ (Case $1-7[\mathrm{~W}]$ ), and $\mathrm{Q}_{\mathrm{H}}$ is found to be $1.8[\mathrm{~W}]$ according to the $\eta_{\text {cell3 }}($ Case $1-7[\mathrm{~W}])$.

Table 6. The results of the PEM fuel cell's heat transfer

\begin{tabular}{|c|c|c|c|}
\hline & $\eta_{\text {cell1 }}$ & $\eta_{\text {cell2 }}$ & $\eta_{\text {cell3 }}$ \\
\hline $\begin{array}{c}\mathbf{Q}_{\text {H }}[\mathbf{W}] \\
(\mathbf{W n e t}=\mathbf{2}[\mathbf{W}])\end{array}$ & 3.0 & 1.1 & 0.5 \\
\hline $\begin{array}{c}\mathbf{Q}_{\mathbf{H}}[\mathbf{W}] \\
(\mathbf{W n e t}=\mathbf{5}[\mathbf{W}])\end{array}$ & 7.5 & 2.8 & 1.3 \\
\hline $\begin{array}{c}\mathbf{Q}_{\mathbf{H}}[\mathbf{W}] \\
(\mathbf{W n e t}=\mathbf{7}[\mathbf{W}])\end{array}$ & 10.5 & 3.9 & 1.8 \\
\hline
\end{tabular}

In Figure 6, it can be seen a diagram of PEM fuel cell's heat transfer. The heat transfer of efficiency (according to the Case 1) reaches a low level of the cell performance. However, The heat transfer of efficiency (according to the Case 3 ) reaches a high level of the cell performance. 


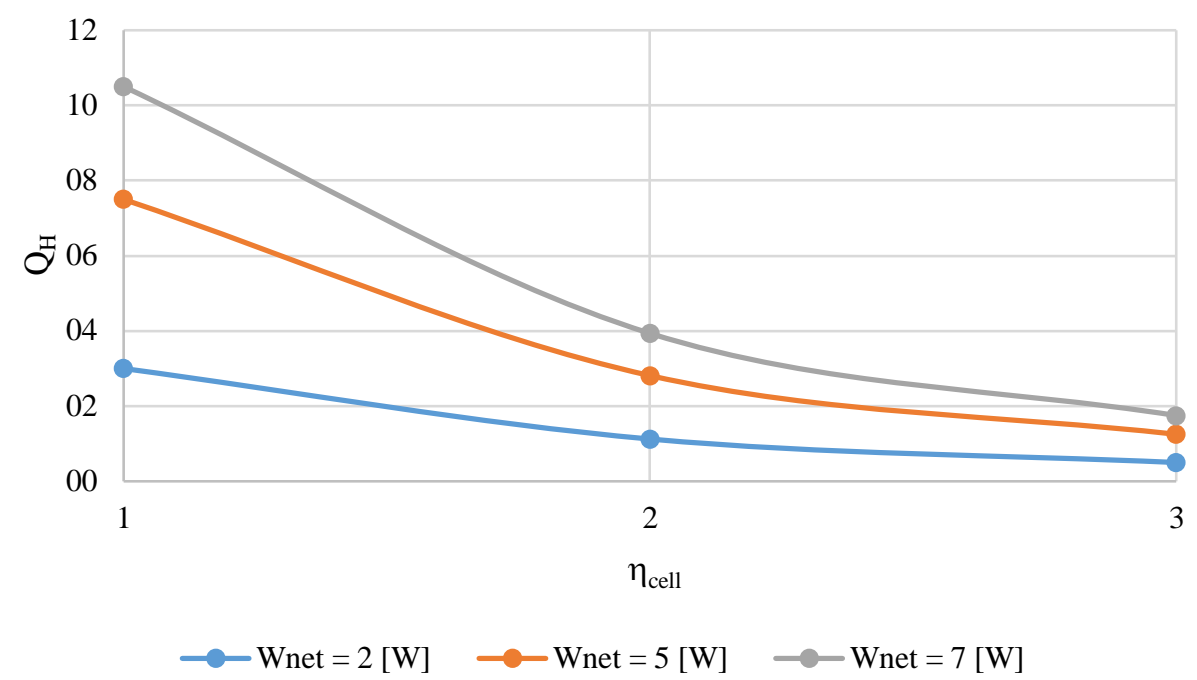

Figure 6. A diagram of PEM fuel cell's heat transfer

In addition, it has been concluded that energy efficiency increases in PEM fuel cell when mass flow and atmospheric conditions are chosen at optimum intervals [14]. In another study, it was mentioned that cell performance efficiency would increase when control of wastewater discharged from the cell is achieved [20]. Mirzae et al. [22] performed the accelerated endurance test and the fuel cell test station that was produced for MEAs with optimum conditions.

In the previous study, $52 \%$ of the performance was found in the experimental study. In the previous experimental study, the system was operated as a pressure 1 bar, 1.5 bar, and 2 bar by keeping the pressure parameters between the parameters 1 and 5 by manually adjusting the pressure regulator. These parameters were examined over a period of time. In the PEM fuel cell, the $\mathrm{H}_{2}$ for proton ion entered the anode reaction portion through the catalyst. $\mathrm{H}_{2}$ passed through the membrane to produce electricity by the action of electrons. To create a reaction in the cathode part, electrons reacted chemically with $\mathrm{O}_{2}$ electrons. Chemical reactions began to occur at each electrode. Finally, the cycle was completed in the PEM fuel cell. The air and fuel in the PEM fuel cell passed through the catalyst layers and the fuel flow layer passed to the right side of the PEM fuel cell membrane. Water vapor, which was produced in the PEM fuel cell system, was the outlet in the system [7].

Wilberforce [40] reported that the pressure drop, along with water management in the fuel cell, has been affected by some changes to help reduce the pressure drop between the flow channels. In this experimental study, it was found that pressure affects fuel cell performance. Thus, the calculations made under these conditions were demonstrated.

According to Table 4, a unit energy cost was found to be 42.6 [\$/W] and the annual energy cost was determined as 25.48 [\$/y]. Finally, the simple payback period was calculated as 0.81 [y]. This result showed that durability and water production in the PEM fuel cell could become more efficient when optimum conditions were achieved in the fuel cell parameters.

Purge parameters (purge interval and duration) are optimized by wastewater discharge. The optimum purge time and purge range for the fuel cell was found to be 10 seconds. With this optimization of working condition parameters, it was determined that hydrogen purity had a very strong effect on total wastewater energy. Increased hydrogen purity will also improve performance. In the literature, it is seen that various flow design channel and membrane designs in PEM fuel cells directly increase energy production. In this way, PEM fuel cell optimum membrane selection and flow channel design is expected to be a model for future similar studies.

\section{CONCLUSION}

In this study, it was determined that combined and different flow channel designs increased fuel cell performance. In addition, it was seen that wastewater management in PEM fuel cells was provided in optimum conditions in appropriate membrane production and selection. 
The result of the techno-economic analysis is determined as Case 3 (7 [W]), which is selected for the best result. The result of energy consumption was found to be $42.6[\$ / \mathrm{W}]$. The total of the energy yield is calculated as 25.48 [ $\$ / y]$. In addition, the simple payback period is found to be $0.81[\mathrm{y}]$.

At the end of this study, following the micro-scale modeling and simulation studies in PEM fuel cells, it was seen that techno-economic analysis should be performed and optimum energy production should be determined according to the appropriate parameters. According to the experimental studies, the PEM fuel cell was found to be original and novel. This is due to the fact that the choice of the membrane in the PEM fuel cell increases performance when selected in accordance with the energy permeability.

According to these results, the cost decreases as power density increases. But the initial investment cost remains high. In order to solve this problem, hydrogen gas should be used continuously and for a long time as fuel. In addition, it is obvious that the material is chosen as a high-temperature resistant material. As a result of these studies; it is expected to benefit the automotive and energy sectors. Compared to the previous experimental study, the PEM fuel cell was improved energy performance by producing the original design of the fuel cell. In particular, motor vehicles (automotive and aerospace sectors) have been growing increasingly interested in the fuel cell, and the PEM fuel cell demonstrates the increase in R \& D work on the fuel cell.

As a result, the fact that the fuel cell is unique manufacture compared to the previous study makes the performance efficient compared to the previous study. In this study, it is seen that the control of water production in PEM fuel cell increases the life and durability of the fuel cell and it provides a great advantage based on the other study. Thus, it was determined that the life and cost of PEM fuel cell could be increased by adjusting the water production amount.

\section{ACKNOWLEDGMENT}

This study was funded and supported by Aksaray University Scientific Research Projects Agency (BAP) within the research grant number 2018-003. Besides, some devices and materials used in the experiments in this study were supported by the previous study, and by the Scientific Research Projects Agency of Aksaray University, under the research grant number 2016-030. In addition, this study was presented orally at the Istanbul ICAME2018 Congress.

\section{NOMENCLATURE}

Symbols and Units

$\dot{\mathrm{C}}_{\mathrm{En}} \quad$ The unit of energy consumption, $\$ / \mathrm{W}$

$\mathrm{C}_{\text {cost }} \quad$ Cost of the energy system, $\$$

$\eta_{\text {cell }} \quad$ Cell performance, $\%$

$\mathrm{Cy} \quad$ Total of the energy yield, $\$ / \mathrm{y}$

E Amount of energy, $\mathrm{J}$

En Energy, kJ

F Faraday constant, $\mathrm{C} / \mathrm{mol}$

I Current, A

$\mathrm{m}_{\text {in }} \quad$ Inlet mass, $\mathrm{kg}$

$\mathrm{m}_{\text {out }} \quad$ Outlet mass, $\mathrm{kg}$

P Power, W

$\mathrm{P}_{\mathrm{H} 2} \quad$ Hydrogen gas price, $\$ / \mathrm{kg}$

$P_{\text {SPP }} \quad$ Simple Payback Period, year

Q Mass flow, $\mathrm{kg} / \mathrm{h}$

$\mathrm{Q}_{\mathrm{H}} \quad$ Production of heat, $\mathrm{W}$

$\mathrm{V}_{\text {cell }} \quad$ Tension of fuel cell, $\mathrm{V}$

$\mathrm{W}_{\text {net }} \quad$ Electric power, $\mathrm{W}$

Abbreviations

$\Sigma \quad$ Sum

$\mathrm{H}_{2} \quad$ Hydrogen gas

$\mathrm{O}_{2} \quad$ Oxygen gas 


$\begin{array}{ll}\text { A } & \text { Ampere } \\ \mathrm{C} & \text { Coulomb } \\ \mathrm{e}^{-} & \text {Electron } \\ \mathrm{H}^{+} & \text {Proton hydrogen ion } \\ \mathrm{H}_{2} \mathrm{O} & \text { Dihydrogen monooxygen } \\ \mathrm{GDL} & \text { Gas Diffusion Layer } \\ \mathrm{J} & \text { Joule } \\ \mathrm{l} & \text { liter } \\ \mathrm{PEM} & \text { Proton Exchange Membrane } \\ \mathrm{s} & \text { Seconds } \\ \mathrm{SPP} & \text { Simple Payback Period } \\ \mathrm{t} & \text { Time, } \mathrm{s} \\ \mathrm{V} & \text { Voltage } \\ \text { W } & \text { Watt }\end{array}$

\section{REFERENCES}

[1] Najafi B., Mamaghani A. H., Baricci A., Rinaldi F., Casalegno A. Mathematical modelling and parametric study on a $30 \mathrm{kWel}$ high temperature PEM fuel cell based residential micro cogeneration plant. International Journal of Hydrogen Energy, 40 (3): 1569-1583, (2015).

[2] Saeed W., Warkozek G. Modeling and analysis of renewable PEM fuel cell system. Energy Procedia, 74: 87101, (2015).

[3] Liso V., Araya S. S., Olesen A. C., Nielsen M. P., Kaer S. R. Modeling and experimental validation of water mass balance in a PEM fuel cell stack. International Journal of Hydrogen Energy, 41 (4): 3079-3092, (2016).

[4] Rosich A., Sarrate R., Nejjari F. On-line model-based fault detection and isolation for PEM fuel cell stack systems, Applied Mathematical Modelling, 38 (11-12): 2744-2757, (2014).

[5] Taleb M. A., Godoy E., Bethoux O., Irofti D. PEM fuel cell fractional order modeling and identification, IFAC Proceedings, 47 (3): 2125-2131, (2014).

[6] Mamaghani A. H., Najafi B., Casalegno A., Rinaldi F. Predictive modelling and adaptive long-term performance optimization of an HT-PEM fuel cell based micro combined heat and power (CHP) plant, Applied Energy, 192: 519-529, (2017).

[7] Taner T. Energy and exergy analyze of PEM fuel cell: A case study of modeling and simulations. Energy, 143: 284-294, (2018).

[8] Arshad A., Ali H. M., Habib A., Bashir M. A., Jabbal M., Yan Y. Energy and exergy analysis of fuel cells: A review. Thermal Science and Engineering Progress, 9: 308-321, (2019).

[9] Baniasadi E. Toghyani S., Afshari E. Exergetic and exergoeconomic evaluation of a trigeneration system based on natural gas-PEM fuel cell, International Journal of Hydrogen Energy, 42 (8): 5327-5339, (2017).

[10] Najafi B., Mamaghani A. H., Rinaldi F., Casalegno A. Fuel partialization and power/heat shifting strategies applied to a $30 \mathrm{kWel}$ high temperature PEM fuel cell based residential micro cogeneration plant. International Journal of Hydrogen Energy, 40 (41): 14224-14234, (2015).

[11] Chahartaghi M., Kharkeshi B. A. Performance analysis of a combined cooling, heating and power system with PEM fuel cell as a prime mover. Applied Thermal Engineering, 128: 805-817, (2018).

[12] Zhang X., Chen S., Xia Z., Zhang X., Liu H. Performance enhancements of PEM fuel cells with narrower outlet channels in interdigitated flow field. Energy Procedia, 158: 1412-1417, (2019).

[13] Najafi B., Mamaghani A. H., Rinaldi F., Casalegno A. Long-term performance analysis of an HT-PEM fuel cell based micro-CHP system: Operational strategies. Applied Energy, 147: 582-592, (2015).

[14] Taner T. The micro-scale modeling by experimental study in PEM fuel cell. Journal of Thermal Engineering, 3(6): 1515-1526, (2017).

[15] Wong C.Y., Wong W.Y., Ramya K., Khalid M., Loh K.S., Daud W.R.W., Lim K.L., Walvekar R., Kadhum A.A.H. Additives in proton exchange membranes for low- and high-temperature fuel cell applications: A review. International Journal of Hydrogen Energy, 44 (12): 6116-6135, (2019).

[16] Sankar K., Jana A. K. Nonlinear multivariable sliding mode control of a reversible PEM fuel cell integrated system. Energy Conversion and Management, 171: 541-565, (2018).

[17] Bao C., Ouyang M., Y1 B., Analysis of water management in proton exchange membrane fuel cells, Tsinghua Science and Technology, 11 1: 54-64, (2006).

[18] Zhang F. Y., Yang X. G., Wang C. Y., Liquid water removal from a polymer electrolyte fuel cell, Journal 
Electrochemical, 153 (2): 225-232, (2006).

[19] Zhang F. Y., Advani S. G., Prasad A. K., Performance of a metallic gas diffusion layer for PEM fuel cells, Journal of Power Sources, 176 (1): 293-298, (2008).

[20] Arbabi F., Roshandel R., Karimi Moghaddam G., Numerical modeling of an innovative bipolar plate design based on the leaf venation patterns for PEM fuel cells, IJE Transactions C: Aspects, 25 (3): 177-186, (2012).

[21] Dokkar B., Settou N., Imine O., Negrou B., Saifi N., Chennouf N., Simulation of water management in the membrane of PEM fuel cell, EFEEA'10 International Symposium on Environment Friendly Energies in Electrical Applications, Ghardaia, Algeria, 1-4, (2010).

[22] Mirzaei F., Parnian M.J., Rowshanzamir S., Durability investigation and performance study of hydrothermal synthesized platinum-multi walled carbon nanotube nanocomposite catalyst for proton exchange membrane fuel cell, Energy, 138: 696-705, (2017).

[23] La Manna J. M., Chakraborty S., Zhang F. Y., Mench M., Gagliardo J., and Owejan J., Isolation of transport mechanisms in PEFCs with high resolution neutron imaging, Electrochemical Society ECS Transactions, 41 (1): 329-336, (2011).

[24] Kong I.M., Jung A., Kim Y.S., Kim M.S., Numerical investigation on double gas diffusion backing layer functionalized on water removal in a proton exchange membrane fuel cell, Energy, 120: 478-487, (2017).

[25] Taner T., Naqvi S. A. H., Ozkaymak M. Techno-economic analysis of a more efficient hydrogen generation system prototype: A case study of PEM electrolyzer with Cr-C Coated SS304 bipolar plates. Fuel Cells, 19 (1): 19-26. (2019).

[26] Taner T. Optimisation processes of energy efficiency for a drying plant: A case of study for Turkey. Applied Thermal Engineering, 80: 247-260, (2015).

[27] Taner T., Sivrioglu M. Thermoeconomic analysis for the power plants of sugar factories. Journal of the Faculty of Engineering and Architecture of Gazi University, 29 (2): 407-414, (2014).

[28] Kim D.J. A new thermoeconomic methodology for energy systems. Energy, 35: 410-422, (2010).

[29] Dahlhausen M., Heidarinejad M., Srebric J. Building energy retrofits under capital constraints and greenhouse gas pricing scenarios. Energy and Buildings, 107: 407-416, (2015).

[30] Weissbach D., Ruprecht G., Huke A., Czerki K., Gottlieb S., Hussein A. Energy intensities, EROIs (energy returned on invested), and energy payback times of electricity generating power plants. Energy, 52: 210-221, (2013).

[31] Zare V. A comparative exergoeconomic analysis of different ORC configurations for binary geothermal power plants. Energy Conversion and Management, 105: 127-138, (2015).

[32] Pragma Industries USB Eload yazılımı, (2016).

[33] Haghighi M., Sharifhassan F. Exergy analysis and optimization of a high temperature proton exchange membrane fuel cell using genetic algorithm, Case Studies in Thermal Engineering, 8: 207-217, (2016).

[34] Zhang X., Guo J., Chen J. The parametric optimum analysis of a proton exchange membrane (PEM) fuel cell and its load matching, Energy, 35: 5294-5299, (2010).

[35] Ahmadi M. H., Mohammadi A., Pourfayaz F., Mehrpooya M., Bidi M., Valero A., Uson S. Thermodynamic analysis and optimization of a waste heat recovery system for proton exchange membrane fuel cell using transcritical carbon dioxide cycle and cold energy of liquefied natural gas, Journal of Natural Gas Science and Engineering, 34: 428-438, (2016)

[36] Gimba I. D., Abdulkareem A. S., Jimoh A., Afolabi A. S. Theoretical energy and exergy analyses of proton exchange membrean fuel cell by computer simulation, Journal of Applied Chemistry, Volume 2016: 1-15, (2016)

[37] Dincer I., Rosen M. A., Exergy. 2nd ed. Chapter 15, Elsevier, Oxford, ISBN 978-0-08-097089-9, (2013).

[38] Larmine J., Dicks A. Full cell systems explained, Second Edition, John Wiley \& Sons Ltd., Chester, ISBN 0-470-84857-X, (2003).

[39] Purnima P., Jayanti S. A high-efficiency, auto-thermal system for on board hydrogen production for low temperature PEM fuel cells using dual reforming of ethanol, International of Hydrogen Energy, 41: 1380013810, (2016).

[40] Wilberforce T., El-Hassan Z., Khatib F.N., Al Makky A., Mooney J., Barouaji A., Carton J. G., Olabi AbdulGhani. Development of Bi-polar plate design of PEM fuel cell using CFD techniques, International Journal of Hydrogen Energy, 42 (40): 25663-25685, (2017). 